\title{
PEREMPUAN PENAMBANG PASIR DAN BATU DI DAERAH ALIRAN SUNGAI GENDOL (QUOVADIS STRATEGI BERTAHAN HIDUP DAN KERUSAKAN LINGKUNGAN DI LERENG MERAPI)
}

\author{
Hastuti \\ Email:hastuti@uny.ac.id \\ Universitas Negeri Yogyakarta
}

\begin{abstract}
Abstrak
Penelitian dilakukan terhadap perempuan penambang pasir dan batu di DAS (Daerah Aliran Sungai) Gendol, Lereng Merapi Kabupaten Sleman, bertujuan untuk mendeskripsikan karakteristik sosial ekonomi dan strategi bertahan hidup perempuan penambang pasir dan batu dan mengetahui kerusakan lingkungan yang ditimbulkan dari penambangan pasir dan batu. Penelitian ini mengandalkan data melalui diskusi dirancang dengan Focus Group Discussion dan wawancara mendalam (indepth interview) menggunakan panduan pertanyaan penelitian. Data responden berupa karakteristik sosiodemografis, masalah ekonomi rumah tangga, strategi bertahan hidup, dan pengetahuan tentang lingkungan mereka. Data deskriptif dianalisis dengan konten analisis. Hasil penelitian perempuan penambang pasir dan batu merupakan perempuan dari rumah tangga miskin. Perempuan melakukan variasi strategi bertahan hidup dengan diversifikasi sumber pendapatan dan mengurangi pengeluaran rumah tangga. Penambangan pasir dan batu disadari perempuan memberikan dampak pada kerusakan lingkungan namun kegiatan tersebut tetap dilakukan perempuan karena dengan cara itu perempuan penambang pasir dan batu bertahan hidup.
\end{abstract}

Kata Kunci: Perempuan Penambang-Strategi Bertahan HidupKerusakan Lingkungan 
Perempuan Penambang Pasir dan Batu ...

\section{Abstract}

This research was conducted among sand and stone female miners in Gendol riverbank, Merapi slope, in Sleman regency. It aims at describing women's social and economical characteristic and their life strategy and also finding the damage of the environment caused by sand and stone mining. The data of this research were collected through focus group discussion and guided in depth interview. Data consist of sociodemographic characteristic, domestic economic problems, life strategy, and their environment knowledge. Data are then analysed using content analysis method. Result shows those women are coming from poor families. Their life strategies are searching various income and limiting family expenses. They aware that sand and stone mining may damage the environment but this is their way to live.

Keywords: women miners, life strategy, damage to the environment

\section{A. Pendahuluan}

Sungai Gendol adalah sungai yang bermuara langsung di lereng Gunung Merapi, ketika terjadi erupsi sungai ini dilalui lahar sehingga penuh dengan batu dan pasir pasca erupsi. Gunung Merapi adalah gunung berapi di Jawa bagian tengah. Gunung ini sering mengalami erupsi sementara lereng ini sangat padat dengan pemukiman penduduk. Bencana yang seringkali terjadi justru dianggap sebagai berkah bagi penduduk Lereng Merapi. Perempuan di Lereng Merapi ketika pasca erupsi memanfaatkan lahar dingin untuk ditambang sebagai sumber pendapatan rumah tangga. Penambangan pasir dan batu merupakan pekerjaan berat yang memerlukan fisik yang kuat untuk melakukannya namun karena kemiskinan, memaksa perempuan harus bekerja. Pekerjaan yang dapat dilakukan adalah mencari pasir dan batu bersama laki- laki dan perempuan lain agar dapat memenuhi kebutuhan rumah tangga. Laki- laki tak selamanya mampu memberi sumbangan pendapatan bagi rumah tangga sehingga peran perempuan untuk memperoleh pendapatan menjadi penting (Jha, 2004: 569).

Perempuan di lereng Merapi memiliki sumberdaya terbatas dihadapkan dengan kompetisi memperoleh sumber pendapatan yang ketat. Kompetisi bukan hanya sesama perempuan tetapi dengan lawan jenisnya agar dapat memenuhi kebutuhan rumah tangganya. Keterbatasan sumberdaya memaksa perempuan harus bekerja seadanya, tanpa persyaratan ketat kecuali persyaratan fisik adalah mencari pasir dan batu. Pekerjaan tersebut biasa dilakukan laki-laki, terpaksa dilakukan perempuan semata-mata untuk memenuhi kebutuhan rumah tangga. 
Pekerjaan berat bagi perempuan dalam membantu mencari nafkah tersebut, tidak berarti mereka dapat menghindar dari menyelesaikan pekerjaan mereka di rumah tangga. Peran ganda perempuan yang selalu disandingkan dengan tugas rumah tangga akan mempengaruhi produktifitas kerja perempuan, kendala tersebut hampir tidak pernah dihadapi laki-laki yang mencari nafkah. Menurut Sajogyo (1986:17), perempuan perdesaan mengalami tekanan pekerjaan rumah tangga dalam melakukan peran ganda. Tekanan pekerjaan ini meliputi status perempuan sebagai isteri, perbedaan penilaian dalam dua macam pekerjaan yang dilakukan dan kesulitan mencari pengganti mengurus rumah tangga. Mengurus rumah tangga, mengurus anak-anak, suami bahkan orang tua merupakan pekerjaan rutin yang harus diselesaikan perempuan sebelum mereka berangkat bekerja mencari pasir dan batu.

Strategi bertahan hidup perempuan dalam rumah tangga yang rentan secara ekonomi, memaksa perempuan harus bekerja seadanya karena dalam pikiran mereka hanya bagaimana kebutuhan rumah tangga mereka dapat tetap terpenuhi. Himpitan kemiskinan memaksa perempuan di Lereng Merapi ikut bekerja dengan menambang pasir meskipun pendapatan yang diperoleh dengan pengorbanan secara fisik kurang signifikan. Perempuan tetap melakukan pekerjaan berat tersebut, meskipun perempuan mengetahui bahwa pilihan pekerjaan yang dilakukan sering harus dihadapkan dengan resiko tertimpa longsoran tanah dari tebing-tebing sungai. Bahkan perempuan mengetahui bahwa tebing sungai yang digali merupakan penyangga jalan apabila digali secara terus menerus dapat mengancam fungsi jalan yang ada.

Strategi bertahan hidup yang dilakukan perempuan dengan mencari pasir dan batu di DAS (Daerah Aliran Sungai) Gendol sebagai upaya untuk menambah pendapatan. Strategi bertahan hidup oleh masyarakat miskin dilakukan dengan menambah pendapatan dan memperkecil pengeluaran, perempuan harus bekerja untuk memperoleh pendapatan sebagai strategi memperoleh pendapatan (Datta, 2006:25). Strategi bertahan hidup guna mengatasi tekanan ekonomi dapat dilakukan melalui strategi yang mengoptimalkan segala potensi anggota rumah tangga, mengurangi pengeluaran rumah tangga, dan memanfaatkan jejaring dengan orang lain baik melalui pertemanan atau ikatan keluarga. Strategi bertahan hidup dengan menambahkan jenis pekerjaan dan merubah pola mata pencaharian seperti pola nafkah ganda dilakukan perempuan untuk memenuhi kebutuhan ekonomi rumah tangga. Strategi bertahan hidup perempuan bukan saja pada sektor ekonomi, akan tetapi berorientasi pada sektor sosial dan kultural (Muica et all; 
2000). Strategi bertahan hidup dilakukan rumah tangga ketika menghadapi kemiskinan antara lain dengan diversifikasi usaha, mengerahkan kekuatan untuk menambah pemasukan atau penghasilan rumah tangga dengan mengerahkan semua anggota rumah tangganya untuk ikut bekerja, berhutang untuk memenuhi kebutuhan hidup, menghemat pengeluaran agar dapat menabung, mengurangi jatah makan, mengurangi kualitas konsumsi makanan, melakukan migrasi untuk memperoleh pekerjaan, dan meminta bantuan dari famili, mencari alternatif sumber pendapatan baru (Meert et all, 2005: 94). Strategi bertahan hidup dengan menambang pasir dan batu menjadi pilihan hidup perempuan di Lereng Merapi. Kehidupan yang dihadapkan dengan himpitan kemiskinan dan keterbatasan sumber daya memaksa perempuan untuk melakukan pekerjaan yang berat dan mengandalkan kekuatan fisik.

Perempuan akan melakukan efisiensi ketika mengalami kesulitan di rumah tangga dengan melakukan: 1 . mengubah diet dan bertahan dengan makanan yang lebih murah sesuai uang yang dimiliki. 2. melakukan sesuatu untuk meningkatkan jumlah makanan yang tersedia dalam jangka pendek. 3. melakukan sesuatu untuk mengurangi jumlah orang untuk diberi makan dalam jangka pendek dan 4. melakukan sesuatu untuk mengelola penjatahan.

In the short term, when there is insufficient food within the household for the people who have to be fed by that household, or insufficient money to buy food, the primary homemaker or person responsible for seeing to it that people are fed can do one or more of the following: 1 . alter the diet, and get by with less expensive foods, according to the money available (dietary change strategies); 2 . Do something to increase the amount of food available in the short term (food seeking strategies); 3 . Do something to decrease the number of people to be fed in the short term (household structure strategies); or 4 . Do something to manage the insufficiency (rationing strategies) (Maxwell, 1999: 414)

Pekerjaan menambang pasir dan batu terpaksa dilakukan karena pekerjaaan tersebut tidak memerlukan persyaratan rumit. Pengambilan batu dan pasir yang banyak dilakukan masyarakat di lereng Merapi pasca erupsi dianggap sebagai peluang untuk memperoleh tambahan pendapatan. Gunung berapi aktif tersebut dianggap bukan saja membahayakan bagi kelangsungan hidup mereka ketika erupsi periodik terjadi tetapi justru sebagai berkah yang mampu menjadi sumber pendapatan rumah tangga. Penambangan pasir dan batu pasca erupsi terus menerus dilakukan oleh masyarakat dari waktu ke waktu sehingga menimbulkan kerusakan lingkungan. Perempuan memahami bahwa menambang pasir dan batu menjadi pilihan sulit yang harus dilakukan untuk 
bertahan hidup meskipun mereka mengetahui bahwa pekerjaan yang dilakukan berpotensi menimbulkan kerusakan lingkungan.

Penambangan pasir dan batu di DAS Gendol ternyata menyebabkan kerusakan lingkungan. Terjadinya kerusakan daerah resapan sehingga mata air berkurang mulai dari Lereng Merapi sampai Kota Yogjakarta dan Bantul. Kerusakan lingkungan akibat penambangan ditandai dengan banyaknya tanah longsor hingga menyebabkan putusnya jalur-jalur evakuasi menjadi fenomena yang dijumpai di Lereng Merapi pasca erupsi. Penambangan pasir dan batu telah menyumbang ekonomi masyarakat Lereng Merapi namun ancaman terhadap kerusakan lingkungan jauh lebih merugikan masyarakat yang akhirnya kontribusi ekonomi tersebut kurang berarti secara signifikan dalam menyumbang kesejahteraan secara luas ( Ikhsan et al. 2009 : 655).

Karakteristik perempuan Lereng Merapi yang dihimpit kemiskinan dan kesulitan untuk akses dan kontrol sumberdaya yang memadai untuk memperoleh pendapatan disebabkan keterbatasan yang dimiliki perempuan seperti rendahnya pendidikan dan keterampilan serta pengetahuan. Rendahnya kualitas sumber daya perempuan menghambat mereka sehingga tidak mampu mengembangkan inovasi pemanfaatan sumber daya yang ada disekitar mereka. Di sisi lain perempuan dihadapkan pada kenyataan, bahwa kegiatan memperoleh sumber pendapatan dengan menambang batu dan pasir dan batu secara terus menerus bukan hanya dapat mengancam jiwa perempuan akibat tertimbun longsoran tebing-tebing sungai, mereka paham apa yang dilakukan akan menyebabkan kerusakan lingkungan. Kerusakan lingkungan yang akan ditimbulkan seperti kesulitan memperoleh pemenuhan kebutuhan air, kerusakan jalan dan lahan pertanian karena longsor dan erosi akibat penambangan yang dilakukan sulit dihindarkan. Solusi untuk membantu perempuan di Lereng Merapi agar memperoleh pendapatan yang layak tanpa harus melakukan penambangan pasir dan batu yang akhirnya menjadi ancaman terhadap kerusakan lingkungan adalah membebaskan perempuan dari belenggu kemiskinan. Miller et al, dalam Ted K. Bradshaw (2015:15), belenggu kemiskinan dapat diatasi melalui peningkatan pendapatan, pendidikan, perbaikan lingkungan, membuka relasi sosial, dan kebijakan kepemimpinan.

Penelitian dilakukan di DAS Gendol, Kecamatan Cangkringan, Kabupaten Sleman tempat perempuan melakukan kegiatan penambangan pasir dan batu. Penelitian dilakukan terhadap sebelas penambang pasir dan batu yang memiliki keragaman karakteristik sosial dan ekonomi. Penelitian ini mengandalkan data yang diperoleh melalui diskusi dirancang dengan baik kelompok terfokus (Focus 
Group Discusion) dan wawancara mendalam (Indepth Interview) menggunakan panduan untuk menjawab pertanyaan penelitian. Data responden berupa "karakteristik sosio demografis, masalah ekonomi rumah tangga, strategi bertahan hidup, dan pengetahuan tentang lingkungan mereka. Analisis data melalui koding secara sistematis dan konten analisis.

\section{B. Pembahasan}

\section{Karakteristik Sosial Ekonomi Perempuan Penambang Pasir Dan Batu}

Profil perempuan dikaji untuk memahami tentang umur, pendidikan, mata pencaharian, penguasaan lahan, dan jumlah anggota rumah tangga. DAS Gendol berada di Kecamatan Cangkringan bermuara langsung di Merapi. Perempuan sebagai penambang pasir dan batu secara tradisional mengandalkan pada kekuatan fisik sehingga umur menjadi variabel penting yang menentukan kelangsungan kegiatan tersebut. Perempuan harus bekerja untuk memperoleh pendapatan guna pemenuhan kebutuhan rumah tangga. Mata pencaharian akan bergantung pada ketersediaan sumber daya di wilayah tersebut, ketika sumber daya semakin terbatas penduduk berupaya melakukan diversifikasi kegiatan guna memenuhi kebutuhan rumah tangga. Perempuan mengalami tantangan berat karena sejak awal tidak dikonstruksi sebagai pencari nafkah utama. Situasi memaksa perempuan kepala rumah tangga harus mencari nafkah sebagai pencari nafkah utama setelah tidak ada lagi suami sebagai pencari nafkah utama. Keterbatasan kesempatan kerja dihadapkan dengan kebutuhan hidup yang meningkat, mengakibatkan kesulitan mencapai kesejahteraan dan memperoleh tambahan pendapatan. Secara eksplisit karakteristik sosio demografi perempuan penambang pasir dan batu adalah sebagai berikut.

Tabel 1. Karakteristik Sosio Demografi Perempuan Penambang Pasir dan Batu

\begin{tabular}{llll}
\hline No & Karakteristik Sosio Demografi & $\mathrm{f}$ & $\%$ \\
\hline 1 & Umur (tahun) & 2 & \\
& $<30$ & 4 & 18,1 \\
& $30-40$ & 3 & 36,6 \\
& $41-50$ & 2 & 27,2 \\
& $>50$ & 11 & 18,1 \\
& Jumlah & & $100 \%$ \\
& Pendidikan & & \\
& Tamat SD & 3 & 27,2 \\
& Tamat SLTP & 7 & 63,8 \\
& Tamat SMA & 1 & 9,0 \\
& Jumlah & 11 & $100 \%$ \\
\hline
\end{tabular}


Hastuti

\begin{tabular}{llll}
\hline $3 \quad$ Mata Pencaharian Sebagai & & \\
Penambang Pasir Dan Batu & & \\
Mata Pencaharian Utama & 10 & 91,0 \\
Mata Pencaharian Sampingan & 1 & 9,0 \\
$\quad$ Jumlah & 11 & $100 \%$ \\
$4 \quad$ Penguasaan Lahan (meter persegi) & & \\
$\quad<1000$ & 9 & 81,9 \\
1000 - 2500 & 2 & 18,1 \\
Jumlah & 11 & $100 \%$ \\
Karakteristik Rumah Tangga & & \\
Pra KS & 8 & 73,8 \\
KS I & 2 & 18,1 \\
KS II & 1 & 9,0 \\
Jumlah & 11 & $100 \%$ \\
\hline
\end{tabular}

Sumber : Data Primer 2015

Dari tabel di atas, Sebagian besar perempuan penambang pasir didominasi usia antara 30 sampai dengan 50 tahun. Penambangan pasir dan batu diperlukan fisik yang kuat, sehingga perempuan yang terlibat pada kegiatan tersebut didominasi kelompok umur produktif. Rata-rata pendidikan perempuan penambang pasir dan batu berlatar belakang SLTP sehingga penambang pasir menjadi mata pencaharian utama. Para perempuan ini hanya memiliki penguasaan lahan yang terbatas yaitu kurang dari 1000 meter persegi dan termasuk keluarga Pra KS.

Pendidikan merupakan salah satu cara meningkatkan kualitas sumber daya manusia. Pendidikan yang memadai menjadikan seseorang mampu menganalisis setiap informasi secara kritis dan menciptakan iklim berpikir yang kreatif dan inovatif. Kemampuan berpikir membuat manusia dapat memanfaatkan setiap kesempatan yang tersedia untuk kesejahteraan hidupnya. Kemampuan berpikir dapat membuka kesempatan lebih luas bagi manusia untuk mengelola sumber daya secara arif, berdaya guna, dan berkelanjutan sehingga bermanfaat bagi kehidupan masa kini dan masa depan. Melalui peningkatan pendidikan diharapkan perempuan memiliki kemampuan meningkatkan kualitas dirinya untuk mengambil keputusan dan melepaskan diri dari belenggu kemiskinan. Pendidikan perempuan penambang pasir dan batu sebagaimana terlihat dalam tabel relatif rendah. Rendahnya pendidikan perempuan menjadi kendala untuk memperoleh sumber pendapatan memadai sehingga sebagian besar perempuan ini menjadikan penambang pasir sebagai mata pencaharian utama. 


\section{Strategi Bertahan Hidup Perempuan Penambang Pasir Dan Batu}

Dinamika di perdesaan berdampak pada makin berkembangnya keanekaragaman kegiatan ekonomi, situasi ini dimanfaatkan masyarakat melakukan diversifikasi sumber pendapatan. Kegiatan penambangan pasir dan batu yang dilakukan perempuan berperan penting memberi sumbangan pendapatan rumah tangga. Ketersediaan lahan garapan yang semakin terbatas tanpa disertai penerapan teknologi pertanian menyulitkan rumah tangga yang bertahan di pertanian. Modal merupakan kendala untuk mengembangkan berbagai kegiatan ekonomi di perdesaan. Kelompok marginal ini merupakan kelompok yang semakin terpuruk dalam kemiskinan, karena tidak memiliki lahan pertanian dan kesulitan modal sebagai tumpuan utama pendapatan rumah tangga. Keterbatasan sumber daya menjadi kendala untuk menguasai sumber pendapatan, sehingga memaksa perempuan bertahan hidup dengan bekerja seadanya. Perempuan penambang pasir dan batu memiliki keterbatasan sumberdaya untuk memenuhi kebutuhan hidup yakni pendidikan rendah, ketiadaan modal, penguasaan lahan pertanian yang sempit. Gambaran ini tercermin dalam wawancara dengan Ibu Miasih dan Ibu Jumiati yang memiliki sumber daya terbatas sehingga pilihan sumber pendapatan yang dilakukan adalah sebagai penambang pasir dan batu.

...setiap hari saya terpaksa menambang di sungai...menambang merupakan satusatunya cara memperoleh sumber pendapatan yang mudah... hanya bermodal cangkul dan sekop...setelah terkumpul saya dapat jual dan memperoleh uang...sambil pulang kerumah mampir ke warung untuk dibelanjakan kebutuhan hari itu ...

Para perempuan penambang pasir ini akan meminjam atau berhutang berbagai kebutuhan ke warung tetangga, apabila hasil penambangan belum terjual. Meskipun pendapatan yang diperoleh hanya dapat untuk memenuhi kebutuhan sehari-hari.

Pekerjaan sebagai penambang pasir yang mengandalkan fisik berdampak pada kesehatan para perempuan ini. Keterbatasan ekonomi menjadikan mereka kurang memperhatikan kesehatan. Umumnya mereka pergi berobat ketika sakit mereka sudah parah. Ibu Miasih dan Ibu Jumiati menyampaikan kondisi mereka

....kalau badan terasa lelah dan sakit seperti pusing dan demam saya pergi ke warung membeli obat...biasanya juga terus sembuh...saya hampir tidak pernah berobat ke dokter...pernah sekali terpaksa ke puskesmas...karena kecelakaan kerja...perempuan harus terus bekerja agar dapur tetap mengepul... 


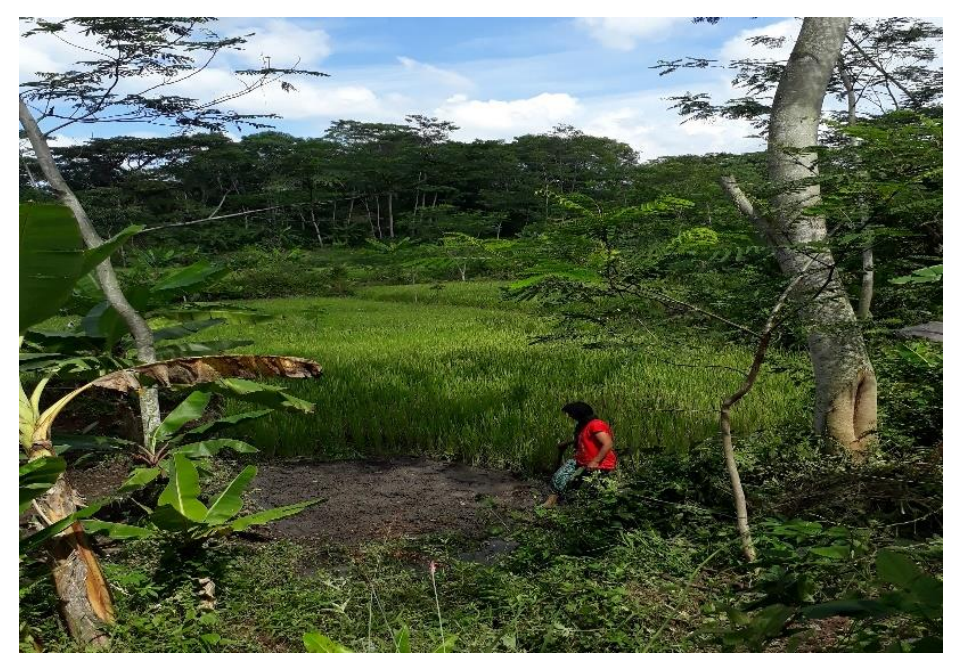

Gambar 1. Aktifitas Perempuan Menambang Pasir Di Bantaran Sungai Gendol

Derajat kesehatan yang buruk akan berdampak pada rapuhnya fisik perempuan sehingga kurang mampu bekerja menambang pasir dan batu. Di sisi lain perempuan kurang memperhatikan cara memelihara kesehatan dengan baik. Mereka baru akan berobat setelah jatuh sakit sementara pencegahan terhadap penyakit diabaikan.

Sistem nilai budaya patriarki yang berlaku di wilayah penelitian menempatkan perempuan melakukan kegiatan yang kurang memiliki nilai ekonomi dan meminggirkan perempuan pada kondisi tidak berdaya. Hal itu dianggap dan diterima sebagai kodrat perempuan dan bersifat alamiah. Perempuan menerima takdir, ikut bekerja mencari nafkah dan harus menyelesaikan tugas rumah tangga. Pekerjaan rumah tangga dapat dilakukan siapapun baik laki-laki maupun perempuan. Sistem nilai budaya patriarki menempatkan perempuan harus bertanggung jawab terhadap pekerjaan rumah tangga tetapi dituntut membantu mencari nafkah. Mengandalkan pendapatan dari kepala rumah tangga akan kesulitan dapat memenuhi kebutuhan rumah tangga yang makin meningkat. Secara simultan peran ini berpengaruh terhadap produktivitas kerja perempuan di sektor produksi karena perempuan harus pandai membagi waktu dan tenaganya di dalam rumah tangga dan di luar rumah tangga.

Perempuan memiliki strategi bertahan hidup untuk kelangsungan hidupnya. Strategi bertahan hidup dilakukan dengan berbagai cara mulai dari diversifikasi usaha, mengerahkan kekuatan untuk menambah pemasukan atau penghasilan rumah tangga dengan beberapa cara: mengerahkan semua anggota rumah tangganya untuk ikut bekerja, berhutang untuk memenuhi kebutuhan hidup, menghemat pengeluaran agar dapat menabung, mengurangi jatah 
makan, mengurangi kualitas konsumsi makanan, melakukan migrasi untuk memperoleh pekerjaan, dan meminta bantuan dari famili melalui silaturahmi. Mengubah pola makan dapat dilakukan mengingat bahan-bahan makanan seperti sayur dan lauk dapat diperoleh dari tanaman di pekarangan mereka juga meminta pada tetangga. Strategi bertahan hidup subsisten menggunakan halaman/pekarangan rumahnya untuk menanam sayur atau rempah-rempah untuk digunakan sendiri.

Tabel 2. Strategi Bertahan Hidup Perempuan Penambang Pasir Dan Batu

\begin{tabular}{|c|c|c|c|}
\hline No & Strategi Bertahan Hidup & $\mathrm{F}$ & $\%$ \\
\hline 1 & Diversifikasi sumber pendapatan & 8 & 73,8 \\
\hline 2 & $\begin{array}{l}\text { Mengerahkan semua anggota rumah tangganya untuk ikut } \\
\text { bekerja }\end{array}$ & 5 & 45,5 \\
\hline 3 & Berhutang untuk memenuhi kebutuhan hidup & 3 & 27,2 \\
\hline 4 & Menghemat pengeluaran agar dapat menabung & 1 & 9,0 \\
\hline 5 & Mengurangi jatah makan & 7 & 63,6 \\
\hline 6 & bantuan dari famili melalui & 1 & 9,0 \\
\hline 7 & Berdagang & 1 & 9,0 \\
\hline
\end{tabular}

Sumber : Data Primer 2015

Perempuan penambang pasir melakukan strategi bertahan hidup dengan diversifikasi sumber pendapatan mencapai 73,8 persen dan mengurangi konsumsi pangan mencapai 63,6 persen. Diversifikasi sumber pendapatan dilakukan perempuan penambang ketika ada kesempatan berusaha seperti berdagang, membuat kerajinan tangan, sebagai sopir ojek, dan mengelola hasil pertanian. Perempuan penambang pasir dan batu sering memilih untuk melakukan beberapa strategi bertahan hidup dalam satu kurun waktu yang sama.

Mengerahkan keluarganya untuk menambah pemasukan atau penghasilan rumah tangga merupakan strategi bertahan hidup yang dilakukan rumah tangga perempuan. Perempuan akan mengerahkan semua anggota rumah tangganya untuk bekerja guna memperoleh pendapatan. Berhutang untuk memenuhi kebutuhan hidup menjadi strategi bertahan hidup. Menghemat pengeluaran agar dapat menabung merupakan strategi bertahan hidup agar ketika ada kebutuhan tak terduga dapat terpenuhi, misal untuk berobat ketika ada anggota rumah tangga yang sakit.

\section{Pengetahuan Perempuan Penambang Pasir Dan Batu Tentang Kerusakan Lingkungan}


Perempuan penambang pasir dan batu memahami bahwa kegiatan yang dilakukan berdampak pada kerusakan lingkungan Penambangan pasir dan batu di DAS Gendol berdampak terhadap kerusakan lingkungan dan sosial budaya. Dampak penambangan menyebabkan terjadi longsor tebing sungai, erosi di wilayah hulu sebagai akibat dari peningkatan kemiringan saluran dan perubahan kecepatan aliran, dan erosi di wilayah hilir karena daya dukung peningkatan sungai, perubahan hilir dalam pola pengendapan, dan perubahan dalam saluran tidur dan tipe habitat. Penambangan pasir dan batu menyebabkan penurunan kualitas air wilayah hilir, terganggunya pertumbuhan vegetasi, perubahan ekologis, dan gangguan habitat serta berkurangnya cadangan air karena terganggunya keberadaan sumber mata air.

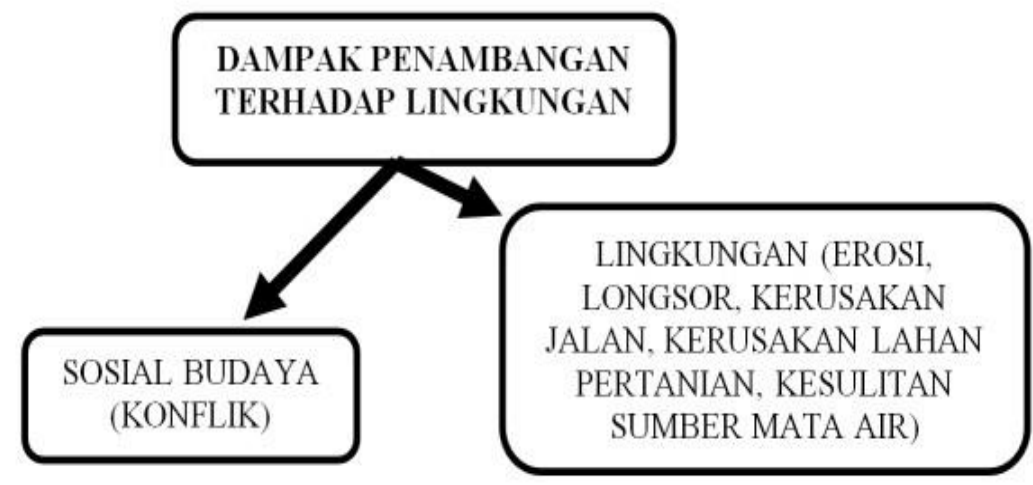

Gambar2. Dampak Penambangan Terhadap Lingkungan

Pengetahuan perempuan penambang pasir terkait dampak yang ditimbulkan akibat kegiatan yang dilakukan meliputi dampak sosial budaya dan kerusakan lingkungan. Konflik terjadi pada kegiatan penambangan meskipun hanya 26,2 persen yang memahami terhadap terjadinya konflik dan 73,8 persen memiliki pengetahuan bahwasanya kegiatan penambangan tidak memunculkan terjadinya konflik. Penambangan pasir dan batu menimbulkan dampak terhadap sosial budaya dan kerusakan lingkungan.

Tabel 3. Pengetahuan Responden Akan Dampak Penambangan

\begin{tabular}{|c|c|c|c|c|c|}
\hline \multirow[t]{2}{*}{ No } & \multirow[t]{2}{*}{ Dampak Penambangan } & \multirow[b]{2}{*}{$\mathrm{f}$} & \multirow{2}{*}{$\begin{array}{l}\text { Ya } \\
\%\end{array}$} & \multicolumn{2}{|c|}{ Tidak } \\
\hline & & & & $\mathrm{f}$ & $\%$ \\
\hline \multirow[t]{2}{*}{1} & Sosial Budaya & & & & \\
\hline & Konflik & 3 & 26,2 & 8 & 73,8 \\
\hline \multirow[t]{4}{*}{2} & Lingkungan & & & & \\
\hline & Erosi & 10 & 90,8 & 1 & 9,1 \\
\hline & Longsor & 11 & 100 & 0 & 0 \\
\hline & Kerusakan Jalan & 11 & 100 & 0 & 0 \\
\hline
\end{tabular}


Perempuan Penambang Pasir dan Batu ...

$\begin{array}{lllll}\text { Kerusakan Lahan Pertanian } & 5 & 45,5 & 6 & 54,5 \\ \text { Kesulitan Sumber Mata Air } & 8 & 73,8 & 3 & 26,2\end{array}$

Sumber: Data Primer 2015

Perempuan penambang pasir dan batu memahami dampak yang ditimbulkan akibat kegiatan penambangan yang dilakukan yakni terjadinya erosi mencapai 90,8 persen, longsor mencapai 100 persen, kerusakan jalan 100 persen, dan kesulitan sumber mata yakni 73,8 persen. Pengetahuan perempuan penambang pasir dan batu memiliki kecenderungan terhadap kerusakan lingkungan bahkan seluruh perempuan memahami adanya kerusakan lingkungan berupa longsor dan kerusakan jalan.

\section{Quovadis Strategi Bertahan Hidup dan Kerusakan Lingkungan}

Strategi bertahan hidup perempuan penambang pasir dan batu menggunakan alternatif subsisten meminta bantuan dari relasi atau jaringan sosial seperti sanak saudara, kawan-kawan dengan memanfaatkan hubungan/relasi sosial. Mekanisme survival dengan cara membentuk relasi sosial melalui lembaga arisan berdasarkan ikatan pertemanan maupun ikatan keluarga yang dikenal dengan 'trah'. Relasi sosial dengan patron juga dikenal dalam relasi sosial perempuan penambang pasir dan batu seperti dengan 'juragan' mereka adalah sosok yang menerima hasil penambangan berupa pasir dan batu, maupun tengkulak dan 'bank plecit'. Relasi sosial bagi mereka yang bekerja pada penambangan pasir dan batu dimanfaatkan juga sebagai pengaman dalam strategi bertahan hidup. Hubungan penambang pasir dan batu dengan pengepul atau tengkulak merupakan hubungan timbal balik yang dianggap saling menguntungkan karena tengkulak yang membeli pasir untuk dijual ke konsumen dan penambang dapat menjual pasir dan batu kepada tengkulak agar segera mendapat uang untuk memenuhi keperluan rumah tangga. Sistem ijon dan pinjaman dengan bunga yang tinggi menjadi alternatif bertahan hidup perempuan penambang pasir dan batu yang memiliki relasi sosial terbatas.

Pengembangan kegiatan ekonomi produktif di perdesaan mengalami kendala modal, penguasaan keterampilan sumber daya manusia, pemasaran, maupun bahan baku. Keterbatasan modal menjadikan kendala utama perempuan dusun penelitian tidak memiliki pilihan untuk melakukan kegiatan produktif. Kegiatan ekonomi produktif dilakukan tanpa dukungan modal yang memadai padahal modal merupakan variabel penting untuk menggerakkan perekonomian di perdesaan. Perekonomian yang ditopang oleh usaha tani maupun diluar usaha tani. Memperoleh modal usaha perempuan sering 
mengalami kesulitan karena persyaratan yang harus dipenuhi dan agunan yang tidak dimiliki perempuan miskin. Perempuan seringkali terjerat pada pinjaman dengan bunga tinggi karena hanya dengan cara seperti itu mereka dapat memperoleh modal. Bahkan ketika perempuan miskin harus menyediakan sejumlah uang untuk keperluan mendesak perempuan miskin terpaksa mengambil pinjaman dengan bunga tinggi. Selain mencari pinjaman dengan bunga tinggi perempuan miskin seringkali terpaksa melakukan ijon yakni memimjam uang kemudian dikembalikan setelah mereka memperoleh pasir dan batu.

Kesulitan memperoleh modal untuk usaha di perdesaan menjadi alasan perempuan sering mengambil jalan pintas dengan mengambil pinjaman meskipun sangat memberatkan bagi perempuan untuk proses pengembalian karena bunga yang tinggi. Modal dari lembaga resmi seperti perbankan menuntut persyaratan ketat sehingga menyulitkan perempuan dapat memperoleh pinjaman dari Bank untuk kegiatan ekonomi produktif mereka.

Tabel 4. Sumber Keuangan / Modal

\begin{tabular}{llll}
\hline No & Sumber Modal / Keuangan & F & $\%$ \\
\hline 1 & Bank Plecit / rentenir & 7 & 63,3 \\
2 & Sistem Ijon & 3 & 27,2 \\
3 & Arisan & 11 & 100 \\
4 & Lembaga keuangan non Bank / BPRdan & 5 & 45,4 \\
\multirow{2}{*}{5} & Bank pemerintah atau swasta & 9 & 81,8 \\
6 & Saudara / tetangga & 9 & 54,5 \\
\hline
\end{tabular}

Sumber Data Primer tahun 2015

Lembaga sosial arisan justru menjadi sumber memperoleh modal yang populer di kalangan perempuan penambang pasir dan batu. Seluruh perempuan memanfaatkan lembaga arisan untuk memperoleh modal meskipun dari lembaga ini perempuan hanya memperoleh modal dalam jumlah kecil dan bergantian dengan sesama anggota arisan. Memperoleh uang tunai untuk modal usaha atau pemenuhan kebutuhan melalui sistem ijon dan memanfaatkan lembaga keuangan tidak resmi/ rentenir masih menjadi pilihan yang banyak dilakukan perempuan Mencari pinjaman kepada saudara atau tetangga juga menjadi pilihan yang banyak dilakukan perempuan untuk memperoleh modal atau uang untuk berbagai kebutuhan. Cara demikian dipahami akan merugikan perempuan, karena nilai jual yang rendah. Ibu Miasih dan Ibu Jumiati terpaksa melakukan ijon, apabila ada kebutuhan mendesak yang harus segera dipenuhi sementara sumberdana tidak dimiliki. 
Perempuan Penambang Pasir dan Batu ...

...mencari pinjaman dengan agunan hasil menambang...harga dipatok rendah oleh pemberi pinjaman...hasil sehari kerja biasanya saya memperoleh uang 150 ribu rupiah...hanya akan memperoleh kurang dari seratus ribu rupiah...terpaksa saya lakukan ketika kebutuhan mendesak...

Penambangan pasir dan batu di DAS Gendol merupakan kegiatan yang menjadi tumpuan pendapatan rumah tangga perempuan penambang. Kendala sumber daya yang dimiliki perempuan memaksa mereka melakukan kegiatan penambangan meskipun mereka mengetahui, bahwa kegiatan yang dilakukan menimbulkan kerugian terhadap keberadaan lingkungan di wilayah tersebut. Bahkan perempuan memiliki pengetahuan bahwa penambangan dapat menyebabkan kerusakan lingkungan secara luas mulai dari erosi, longsor, ketersediaan air yang terganggu mulai dari daerah hulu hingga hilir.

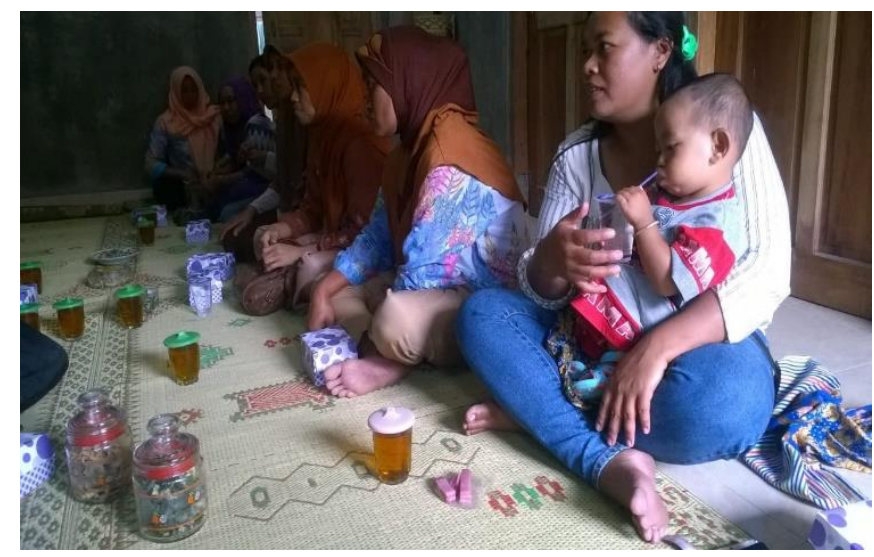

Gambar 3. Diskusi Kelompok Terpimpin Warga Penambang Pasir Sungai Gendol

Kerusakan lingkungan di DAS Gendol Lereng Merapi akibat penambangan pasir dan batu sangat meluas. Kondisi demikian apabila dibiarkan secara terus menerus akan berdampak pada kondisi ekonomi, sosial, dan kultural masyarakat. Terjadinya longsor pada tebing sungai, rusaknya infrastruktur jalan untuk akses ke Lereng Merapi, serta semakin sulit memperoleh sumber mata air. Upaya yang dilakukan untuk pengembangan Lereng Merapi sebagai wilayah yang digunakan sebagai sumber pendapatan melalui kegiatan penambangan pasir dan batu dengan menekan terjadinya kerusakan lingkugan.

Analisis SWOT melihat kondisi DAS Gendol agar dapat dimanfaatkan oleh masyarakat sebagai sumber daya yang memberikan sumber pendapatan dan kondisi lingkungan dapat terjaga sesuai dengan daya dukung lingkungan.

a. Strength (Kekuatan) 
1. Gunung Merapi yang mengalami erupsi periodic adalah sumber pendapatan yang dapat diperoleh warga hampir tanpa mengeluarkan modal selain fisik kuat

2. Menambang pasir dan batu sebagai strategi bertahan hidup

b. Weakness (Kelemahan)

1. Tingkat ekonomi rumah tangga perempuan masih rendah

2. Rendahnya tingkat pengetahuan masyarakat tentang lingkungan

3. Penambangan pasir dan batu secara terus menerus akan merusak lingkungan

4. Pengelolaan lingkungan belum dilakukan dengan benar

c. Opportunities (Peluang)

1. Banyak investor yang ingin investasi dalam usaha penambangan

2. Permintaan pasir Merapi yang tinggi karena kualitas pasir dianggap lebih baik

d. Threats (Tantangan)

1. Wilayah sekitar DAS Gendol termasuk wilayah rawan resiko bencana

2. Penambangan sebagai sumber pendapatan utama rumah tangga

Strategi pengelolaan lingkungan penambangan agar dapat memiliki daya dukung yang baik untuk memperoleh penghidupan yang baik dan kondusif dapat dikaji beberapa kemungkinan strategi melalui analisis komponen kekuatan dan kelemahan kepada faktor peluang dan tantangan.

a. Strategi Strength-Opportunities (SO)

1. Diperlukan sinergi antara masyarakat agar penambangan memberikan kontribusi positif dalam menyumbang pendapatan rumah tangga penambang.

2. Diperlukan cara penambangan pasir dan batu yang memperhatikan konservasi lahan, sehingga dapat menjadikan upaya pengelolaan penambangan pasir di kawasan Gunung Merapi secara berkelanjutan.

b. Strategi Strength-Threats (ST)

1. Diperlukan kebijakan pengelolaan lingkungan penambangan agar mampu menekan terjadinya erosi.

2. Menjaga aksesibilitas wilayah penambangan agar segera berkembang sebagai kawasan dengan diversifikasi usaha yang mapan

Penambangan sebagai pendapatan asli daerah perlu dijaga meskipun pengelolaan lingkungan harus menjadi prioritas 


\section{c. Strategi Weaknes-Opportunities (WO)}

1. Meningkatkan kualitas sumber daya manusia.

2. Meningkatkan pendapatan rumah tangga.

3. Mengoptimalkan pemanfaatan sumber daya alam

\section{d. Strategi Weakness-Threats (WT)}

1. Peningkatan ekonomi masyarakat terutama penambang pasir dan batu

2. Menekan dampak penambangan yakni kerusakan lingkungan.

Peningkatan penghidupan perempuan penambang pasir dan batu menjadi bagian penting untuk meningkatkan taraf hidup mereka. Kualitas penghidupan yang baik akan membawa dampak terhadap lingkungan yang lebih baik. Menurut Datta et all; (2006) bahwa perempuan dengan kualitas sumberdaya rendah akan mengalami marjinalisasi. Marjinalisasi terhadap perempuan akan memaksa perempuan melakukan kegiatan ekonomi seadanya agar dapat bertahan hidup sebagaimana pilihan pekerjaan menambang pasir menjadi sumber pendapatan. Pekerjaan ini berat bagi perempuan ditambah kegiatan tersebut rentan terhadap kerusakan lingkungan.

\section{Simpulan}

Berdasarkan karakteristiknya, perempuan penambang pasir didominasi usia produktif, berpendidikan SLTP, termasuk kelompok rumah tangga Pra KS dengan luas penguasaan lahan kurang dari 0,1 ha. Mata pencaharian sebagai penambang pasir dan batu merupakan sumber pendapatan utama perempuan. Diversifikasi sumber pendapatan dan mengurangi konsumsi pangan menjadi strategi perempuan penambang pasir dalam penghidupan mereka. Pengetahuan perempuan penambang pasir bahwa kegiatan menambang pasir berdampak pada kerusakan lingkungan sangat tinggi bahkan seluruh perempuan penambang paham akan terjadinya longsor dan kerusakan jalan dan 90,8 persen memahami kegiatan tersebut menyumbang terjadinya erosi karena tanaman penutup tidak sempat tumbuh apabila dilakukan penambangan terus menerus. Perempuan penambang pasir dan batu dengan rendahnya kualitas sumber daya yang dimiliki dihadapkan pada dilema bahwa mereka harus melakukan kegiatan penambangan sebagai sumber pendapatan untuk penghidupan mereka disisi lain mereka mengetahui kegiatan yang dilakukan secara potensial menyebabkan kerusakan lingkungan. Upaya yang dapat dilakukan adalah mencari strategi pengelolaan lingkungan dan mencari alternatif kegiatan yang mampu memberikan sumber pendapatan bagi perempuan. 


\section{Daftar Pustaka}

Agus Joko Pitoyo dan Muhammad Arif Fahrudin Alfana, 2015. “Strategi Rumah Tangga Miskin Perdesaan Keluar Dari Kemiskinan: Kasus Tiga Desa Di Kulon Progo, Daerah Istimewa Yogjakarta". Populasi Volume 23 Nomor 2 $55-70$

Bradshaw, Ted K, 2015. Theories of Poverty and Anti-Poverty Programs in Community Development. Revision of papers presented at the meetings of the Community Development Society (2001) and the Rural Sociology Society (2003).

Daniel Maxwell, 1999, Alternative food-security indicators: revisiting the frequency and severity of 'coping strategies'. Food Policy 24 (1999) 411-429 www.elsevier.com/locate/foodpol

Datta, Kavita, et all 2006, Work and survival strategies among low-paid migrants in London. ESRC (Economic Social Research Council) ISBN: 0-902238-24-8.

Eboiyehi, Friday Asiazobor, 2013, “Our Lives are in Your Hands: Survival Strategies of Elderly Women Heads Households in Rural Nigeria dalam International Journal of Humanities and Social Science Vol. 3 No. 5; March 2013 292-302

Jazaul Ikhsan; Masaharu Fujita dan Hiroshi Takebayashi, 2009, "Sustainable Sand Mining Management in Merapi Area Using Goundsills" dalam Annuals of Disaster Prev.Res. Int Kyoto Univ No 52 B, 2009 647-657.

Jha, Nitish. 2004, "Gender and Decision Making in Balinese Agriculture American Ethnologist,Vol. 31, No. 4 (Nov., 2004), pp. 552-572. doi:10.1525/ae.2004.31.4.552

Krantz, L. 200. The Sustainable Livelihood Approach to Poverty Reduction. An Introduction. SIDA. Division for Policy and Socio-Economic Analysis. Stockholm, 2001

Meert, H et all, 2005, "Farm household survival strategies and diversification on marginal farms. Journal of Rural Studies 21 (2005) 81-97

Muica, Nicolae;Turnock, David;Urucu, Veselina, 2000, Coping strategies in rural areas of the Buzau Sub-Carpathians GeoJournal; 2000; 50, 2-3; Technology Collection pg. 157

Sajogyo, 1986. "Pembagian Kerja antara Pria dan Wanita di Bidang Pertanian". Buku Kenang- kenangan untuk Selo Sumardjan. Bogor IPB 
Halaman ini tidak sengaja untuk dikosongkan 